\title{
Insight into ongoing and emerging therapeutic options for COVID-19: a review
}

\author{
Shweta Singla*, Amanjot Kaur, Mandeep Kaur
}

Department of Pharmacology, Adesh Institute of Medical Sciences and Research, Bathinda, Punjab, India

Received: 05 September 2020

Accepted: 08 October 2020

\author{
*Correspondence: \\ Dr. Shweta Singla, \\ Email: drshwetasingla2010@gmail.com
}

Copyright: (C) the author(s), publisher and licensee Medip Academy. This is an open-access article distributed under the terms of the Creative Commons Attribution Non-Commercial License, which permits unrestricted non-commercial use, distribution, and reproduction in any medium, provided the original work is properly cited.

\begin{abstract}
The outbreak of novel coronavirus (COVID-19) has evolved into a global pandemic and has posed significant threats to health and the economy worldwide. It can manifest from mild disease to severe respiratory failure requiring intensive care management. Currently, there is no sufficient evidence that any existing drugs can effectively treat SARS-CoV-2 pneumonia though supportive care remains the mainstay of treatment. However, there are many ongoing clinical trials of potential anti-COVID-19 therapies including the vaccines. In the current review, we Summarized the information available about COVID-19 medications, and treatment options.
\end{abstract}

Keywords: SARS-CoV-2, Antivirals, Cytokine storm, Immunomodulators, COVID-19 vaccine

\section{INTRODUCTION}

Severe acute respiratory syndrome coronavirus 2 (SARSCoV-2) is a novel strain of coronavirus that has not been previously identified in humans. The Chinese Centre for Disease Control and Prevention identified the virus from the throat swab sample of an infected patient on January 7, 2020. ${ }^{1}$ Later, the world health organization (WHO) declared the disease as public health emergency in January 2020 and officially named the disease as COVID-19 in February 2020. ${ }^{2}$ On 11 March 2020, WHO declared SARS-CoV-2 as a pandemic that causes novel coronavirus disease 2019. The incidence of COVID-19 continues to rise, with more than 14, 562, 550 laboratoryconfirmed cases and over 607, 781 deaths worldwide despite rigorous global containment and quarantine efforts to date. ${ }^{3}$

The etiological agent of COVID-19, SARS-CoV2, is a betacoronavirus. It is structurally related to severe acute respiratory syndrome-coronavirus (SARS-CoV) that caused the SARS outbreak in 2002 and the Middle East respiratory syndrome coronavirus (MERS-CoV) that caused the MERS outbreak few years later. ${ }^{4}$ These coronavirus strains have been responsible for epidemics and high fatality rates in the past two decades.

Till now the exact source of SARS-CoV-2 has not been identified but the Phylogenetic analysis suggests the zoonotic origin of this virus. ${ }^{5}$ It's spread and transmission among humans occurs via close contact with an infected individual by means of contact and large droplets. ${ }^{6}$ To limit the spread of the virus and the disease worldwide, the healthcare authorities have taken measures like quarantining the infected patients, aggressive testing and rapid diagnosis of suspected patients, use of appropriate masks along with the implementation of strong restrictions over international travel of a large number of individuals exposed to SARS-CoV-2 without being detected. $^{7}$

Most people infected with SARS-CoV2 experience common clinical symptoms like fever, non-productive cough, myalgia, shortness of breath and recovery with supportive care but certain hosts may develop a 
precipitous clinical decline. ${ }^{8}$ In addition, there may be pneumonia, severe acute respiratory syndrome, kidney failure, and death. ${ }^{9}$ Current data suggests that triggering of hyperimmune host reactions by the virus are partially responsible for these poor outcomes. ${ }^{10}$ To ameliorate the disease and hasten the recovery in this high- risk population, early identification and intervention are required.

There is no specific treatment available and the current treatment relies on supportive care of the infected patients. The suppression of viral outbreaks is most effective if the pathogen is detected early and timely interventions are established. Although, in vitro and in vivo studies have shown promising results with various molecules against coronaviruses, but none of these agents have proven to be effective in humans. Further research is needed to evaluate the effectiveness of the drugs so that the pandemic can be controlled at the earliest. This review is planned to provide information about available treatment options and the possible role of repurposing drugs, and alternative medicines for the management of COVID-19 disease.

\section{ANTI VIRAL DRUGS}

\section{Remedesivir}

Remdesivir (GS-5734) is an antiviral agent undergoing phase 3 clinical trials for the treatment of COVID-19. In vitro and in vivo animal data suggest broad antiviral spectrum against paramyxoviridae, filoviridae, and the coronaviridae including MERS-CoV, SARS-CoV, and SARS-CoV-2. ${ }^{11}$ Remdesivir was initially developed for the treatment of Ebola hemorrhagic fever; however, it has not been approved globally for any indication. ${ }^{12}$ In vitro studies in human airway epithelial cell cultures in a lung model have found some activity against corona-viruses. ${ }^{13}$

In its active triphosphate nucleoside form, remdesivir binds to ribonucleic acid (RNA)-dependent RNA polymerase and acts as RNA-chain terminator. Remdesivir is highly selective for viral polymerases and is expected to be less toxic to human cells. It displays potent in vitro activity against SARS-CoV-2 with (half maximum effective concentration) EC50 at 48 hours of $0.77 \mu \mathrm{M}$ in Vero E6 cells. ${ }^{14}$ It is a potent inhibitor of this virus replication in human nasal and bronchial airway epithelial cells. ${ }^{15}$ Similar activity has been demonstrated against other zoonotic coronaviruses (SARS-CoV-1 and MERS-CoV). ${ }^{16}$

Remdesivir is manufactured as a lyophilized powder that requires reconstitution and is administered intravenously over 30 minutes. ${ }^{17}$ The dose under investigation for the treatment of COVID-19 is $200 \mathrm{mg}$ intravenously (IV) on day 1 followed by $100 \mathrm{mg}$ IV daily and can be given for up to 10 days, infused over $30-60$ minutes in adult patients. $^{18}$
Therapeutic remdesivir treatment initiated early during infection has shown significant antiviral and clinical effects in the form of reduced pulmonary infiltrate and virus titres in bronchoalveolar lavage in the SARS-CoV-2 affected rhesus macaque model. So, this data supports that early remdesivir administration in COVID-19 patients may prevent progression to severe pneumonia. ${ }^{19}$ Patients reported with nausea, vomiting, gastroparesis, rectal bleeding along with elevated aminotransferase levels occurring within 1-5 days of start of remedesivir. ${ }^{20}$ However, it is not yet clear whether this laboratory change is due to the drug itself or the viral disease.

In the latest clinical trial, remdesivir was found to be superior to placebo in shortening the recovery time in patients hospitalized with COVID-19 and evidence of lower respiratory tract infection. ${ }^{21}$ Intravenous remdesivir has been utilized on the basis of individual compassionate use in patients hospitalized with COVID-19 in some countries and benefit has been reported in sick patients.

Food and drug administration issued an emergency use authorization (EUA) for remdesivir for the treatment of hospitalized patients with severe COVID-19 in adults and children with a view that it may shorten the time taken to recover. ${ }^{22}$ However, the clinical and antiviral efficacy of remdesivir in COVID-19 still remains to be established.

\section{Favipiravir}

Favipiravir (FPV), a prodrug, is a novel RNA-dependent RNA polymerase (RdRp) inhibitor, has been shown to be effective in the treatment of influenza and ebola virus. ${ }^{23}$ Recently, a report from wang et al showed that both FPV and remdesivir are effective in reducing the SARS-CoV2 infection in vitro $(\mathrm{EC} 50)=61.88 \mu \mathrm{M}$, half cytotoxic concentration (CC50) $>400 \mu \mathrm{M}$, selectivity index (SI)>6.46). ${ }^{24}$ This study highlighted FPV as a potential clinical intervention for COVID-19. Favipiravir can cause adverse effects like hyperuricemia, increase in transaminase levels, neutropenia, diarrhoea along with prolonged QT interval during treatment, which should be monitored during medication. ${ }^{25}$

In a recent clinical trial, the effects of favipiravir (FPV) were compared with that of lopinavir LPV/r in the laboratory-confirmed COVID-19 patients. These groups were compared for changes in chest computed tomography (CT), viral clearance, and drug safety. In this open-label study, FPV showed better therapeutic responses in COVID-19 in terms of disease progression. ${ }^{26}$

\section{Lopinavir/ritonavir}

Lopinavir is a HIV-1 protease inhibitor administered in fixed-dose combination with Ritonavir (LPV/r), which is a potent CYP3A4 inhibitor that "boosts" lopinavir concentrations. Protease inhibitors primarily exert antiviral effect by preventing viral replication, thus limiting spread into host cells. Lopinavir has efficacy 
against 3-chymotrypsin-like protease of MERS and SARS. ${ }^{27}$ The therapeutic rationale for LPV/r arises from in vitro studies demonstrating inhibition of the 3chymotrypsin like protease found in novel coronaviruses. $^{28}$

Most recently, Cao et al reported the results of an open label randomized trial comparing LPV/r 400/100 mg twice daily $(n=99)$ to standard care $(n=100)$ for treatment of pneumonia in COVID-19 disease. There was no difference between treatment arms in reduction of viral loads over time between the 2 groups. ${ }^{29}$ From the available evidence from various in vitro studies, lopinavir/ritonavir is used as an adjunctive agent for COVID-19, and the dose of $400 \mathrm{mg} / 100 \mathrm{mg}$ by mouth twice/day is recommended for 14 days. Treatment with $\mathrm{LPV} / \mathrm{r}$ may result in intolerable gastrointestinal adverse effects.

\section{Ribavirin}

Ribavirin, a guanosine analog, is a broad-spectrum antiviral drug. It has been used to treat several virus infections, including respiratory syncytial virus, hepatitis $\mathrm{C}$ virus, and some viral hemorrhagic fevers. Ribavirin triphosphate inhibits RNA polymerase of influenza virus, thereby interfering with virus replication. ${ }^{30}$ When ribavirin was used in combination with IFN- $\alpha 2 b$, the antiMERS-CoV activity of ribavirin was significantly enhanced in rhesus macaques. ${ }^{31}$ Ribavirin has shown to inhibit SARS-CoV replication in five different cell types derived from animals or humans at therapeutically achievable concentrations. After sequence analysis, it has been seen that ribavarin can target SARS-CoV-2 RNAdependent RNA polymerase ( $R d R p)$ model and it is this feature that supports its potential as an antiviral against this virus. In terms of adverse effects hemolytic anemia, hypocalcemia, and hypomagnesemia have been reported in patients treated with ribavirin for severe acute respiratory syndrome. ${ }^{32}$ Given the efficacy of ribavirin in the treatment of diseases caused by SARS-CoV and MERS-CoV, it is expected to become an effective drug for COVID-19 treatment. However, the efficacy of ribavirin for the treatment of COVID-19 is still controversial, and needs further confirmation via clinical trials.

\section{OTHER DRUGS}

\section{Chloroquine and Hydroxychloroquine}

These 4-aminoquinoline antimalarials have been tried in the treatment of COVID-19. Chloroquine (CQ) can inhibit $\mathrm{pH}$-dependent steps of replication of several viruses. ${ }^{33}$ Moreover, it also works as a novel class of autophagy inhibitor, which might interfere with viral replication and thus infection. Studies have shown its interference with glycosylation of ACE receptors of COVID-19 at both entry and post-entry stages. ${ }^{34}$
With the view of better tolerability, hydroxychloroquine (HCQ) that differs from chloroquine only by a single hydroxyl group has gained interest. In a two-part study to assess the comparative in vitro activity, pharmacology based pharmacokinetic study performed by $\mathrm{Yao}$ et al demonstrated the potency of HCQ (EC50 of $0.72 \mu \mathrm{M}$ ) to be greater than CQ (EC50 of $5.47 \mu \mathrm{M})$ against SARSCoV-2.35 CQ has good oral bioavailability, wide distribution and is metabolized by cytochrome $\mathrm{P} 450$ (CYP) 2C8 and CYP3A4.

The impact of 200mg of HCQ every 8 hourly in COVID19 positive patients has been well established in a study by Gautret et al. The investigators demonstrated that HCQ was superior to the standard care in clearance of SARS$\mathrm{CoV}$ from the nasopharynx. In addition to it, 6 patients in the study were prescribed Azithromycin to prevent bacterial super-infection and the viral clearance was $100 \%$ in patients receiving both HCQ and Azithromycin in contrast to HCQ given alone. ${ }^{36}$

Macrolides and 4 aminoquinolones have been associated with cardiotoxicity as evidenced by QT prolongation which poses an increased risk of Torsades de pointes and sudden cardiac death. Thus, is it really safe to use HCQ and Azithromycin in combination is questionable and this needs to be answered. HCQ has a better safety profile in contrast to Chloroquine As there are currently no efficacy data available for HCQ in COVID-19, thus additional consideration needs to be taken to optimize the drug therapy.

\section{Human monoclonal antibody}

The monoclonal antibodies such as tocilizumab and sarilumab are effective and have been employed in rheumatoid arthritis and they act by inhibiting IL-6 receptors. Moreover, COVID-19 severity depends on excessive pro-inflammatory markers production suggesting that cytokine storms are involved in COVID19. ${ }^{37}$ The results with Tocilizumab have been encouraging as three seriously ill patients have shown improvement on drug administration. ${ }^{38}$ The dose of the drug in COVID-19 is not well established but it was administered at a dose of $400 \mathrm{mg}$ intravenously in a case series of patients. ${ }^{39}$ However, adverse effects such as infusion-related reactions, infection, neutropenia, thrombocytopenia, increased liver enzymes and abnormalities in lipid profile can occur.

Itolizumab is a humanized recombinant anti-CD6 IgG1 monoclonal antibody that had been approved for the treatment of psoriasis. ${ }^{40}$ Repurposing of itolizumab for emergency use for the treatment of 'cytokine' release syndrome in moderate to severe acute respiratory distress syndrome patients due to COVID-19 has recently gained some importance. ${ }^{41}$ Further efficacy and safety of this drug in COVID 19 disease need to be studied. 


\section{Intravenous immunoglobulins}

They are purified intravenous immunoglobulins (IVIg) products prepared from pooled human plasma and has been used extensively for treating inflammation related diseases. Intravenous IG elicits its passive immunity and anti-inflammatory effects by supplying idiopathic antibodies, binding to Fc receptors that suppress pathogenic cytokines and prevent formation of membranolytic attack complexes as well as modulates $\mathrm{T}$ cell function. Thus, it is considered as a therapeutic option for hyper-inflammation in patients with severe COVID19. In a case series on use of IVIg (at a dose of 0.3-0.5 $\mathrm{g} / \mathrm{kg} /$ day for 5 days) in three patients suffering from SARS-CoV2, with lymphopenia and elevated inflammatory markers, clinical improvement has been observed in terms of normalisation of temperature and relieve of breathing difficulties in 5 days. However, the concurrent usage of antivirals in two patients and steroids use in one patient were the confounding factors in this study. ${ }^{42}$ To alert on the potential and severe adverse effects (transfusion related), a clinical trial has been initiated with IVIg. ${ }^{43}$

\section{Corticosteroids}

Corticosteroids were used in the previous outbreaks of SARS-CoV and MERS-CoV, and are also being now used in patients with 2019-nCoV in addition to other therapeutics. ${ }^{44}$ Patients with severe COVID-19 develop a systemic inflammatory response that can lead to lung injury and multisystem organ dysfunction. So, the antiinflammatory effects of corticosteroids might prevent these harmful effects. The significance as well as controversy both exists when it comes to use of corticosteroids in severe pneumonia due to coronaviruses. Thus risk-benefit assessment should be done on an individual basis by clinicians. Till now, clinical data has revealed that the use of corticosteroids in COVID 19 patients increases the risk of prolonged mechanical ventilation, avascular necrosis, delayed viral clearance, and some secondary infections. ${ }^{45}$

However, great variation exists in selecting the agent and dosage, as it can impact both safety and efficacy. Based on the preliminary data of the ongoing RECOVERY trial (the randomised evaluation of COVID-19 therapy), dexamethasone $6 \mathrm{mg}$ daily for up to 10 days is recommended in patients with COVID-19 who are on mechanical ventilation or require oxygen supplementation. ${ }^{46}$ The value of corticosteroid therapy for patients with COVID-19 needs reconsideration.

\section{Convalescent plasma}

Convalescent plasma (CP) is a strategy of passive immunization by obtaining plasma using apheresis in survivors of prior infection and then administering to any individual who is susceptible or infected with the disease. To obtain plasma, apheresis is the common procedure, which allows centrifuging blood from donor to allow a selective plasma collection. The plasma for transfusion must be obtained from donors who test negative for COVID-19 when plasma collection is performed, and before 28 days of clinical recovery and in addition, must be collected from patients who are asymptomatic for minimum of 14 days. ${ }^{47}$ The transfusion dose of CP is not standardized, however, currently the dose recommended is $3 \mathrm{ml} / \mathrm{kg} /$ dose in two days. ${ }^{48}$ The most common adverse effects with CP therapy are transfusion-related events such as chills, fever, anaphylactic reactions, circulatory overload and haemolysis. Many investigational agents are under research for COVID-19 and some of them are summarized (Table 1).

Table 1: Investigational treatment approaches for COVID-19.

\begin{tabular}{|c|c|c|c|}
\hline S. no. & Other drugs & Mechanism & Comments \\
\hline 1. & Barcitinib & $\begin{array}{l}\text { JAK-STAT and Numb associated kinase } \\
\text { inhibitor, considered to be effective against } \\
\text { the effects of high cytokines (including } \\
\text { interferon alpha) in COVID-19. }\end{array}$ & $\begin{array}{l}\text { During COVID-19 outbreak, it had been paired } \\
\text { with direct acting antivirals, and had shown } \\
\text { decrease in viral infectivity, replication and an } \\
\text { abnormal inflammatory response. }{ }^{49}\end{array}$ \\
\hline 2. & Bevacizumab & $\begin{array}{l}\text { Prevents biological activity of Vascular } \\
\text { endothelial growth factor (plays a key role in } \\
\text { acute lung injury) }\end{array}$ & $\begin{array}{l}\text { Two trials are evaluating its efficacy and safety } \\
\text { in COVID-19 (BEST-RCT and BEST-CP). } .^{50}\end{array}$ \\
\hline 3. & Eculizumab & $\begin{array}{l}\text { A monoclonal antibody, inhibitor of the } \\
\text { terminal portion of the complement cascade } \\
\text { involved in the inflammatory response. }\end{array}$ & $\begin{array}{l}\text { In SOLID-C19 trial in the treatment of patients } \\
\text { with severe SARS-CoV and ARDS. }{ }^{51}\end{array}$ \\
\hline 4. & Ivermectin & $\begin{array}{l}\text { Broad spectrum anti parasite drug has shown } \\
\text { its ability in invitro study, to inhibit viral } \\
\text { replication up-to } 5000 \text {-fold (mediated by } \\
\text { inhibiting nuclear transport receptor } \\
\text { importin alpha/beta). }{ }^{52}\end{array}$ & $\begin{array}{l}\text { The drug is in randomised, double blind trial to } \\
\text { assess the safety and efficacy profile in } \\
\text { combination therapy with HCQ in COVID-19 } \\
\text { hospitalised patients. }{ }^{53}\end{array}$ \\
\hline 6. & Thalidomide & $\begin{array}{l}\text { Anti-inflammator, speeds up degradation of } \\
\text { messanger RNA in blood cells and reduce } \\
\text { TNF-alpha. }\end{array}$ & $\begin{array}{l}\text { Used in two trials (NCT04273581 and } \\
\text { NCT04273529) against COVID-19. }{ }^{54}\end{array}$ \\
\hline 7. & Vitamin C & Antioxidant and Immunomodulatory & $\begin{array}{l}\text { A clinical trial to investigate the effects of } \\
\text { vitamin } C \text { infusion has been started. } .^{55}\end{array}$ \\
\hline
\end{tabular}




\section{COVID-19 VACCINE STATUS}

According to the WHO latest count, 23 vaccine candidates are in the various phases of clinical trials in human beings and 140 vaccine candidates are in the preclinical stage of evaluation. ${ }^{56}$ From above 23 vaccine candidates, two vaccines are presumed to be the frontrunners at present. $^{57}$ One is ChAdOx-S vaccine which is non-replicating viral vector vaccine currently in phase III of clinical trials being developed by University of oxford in collaboration with astra zeneca, British based company. Preliminary report of Phase $1 / 2$ clinical trials on the safety and immunogenicity of this vaccine against SARS-COV-2 is published on 20th July, 2020. ${ }^{58}$ Another vaccine is mRNA 1273 vaccine which is novel lipid nanoparticle (LNP)-encapsulated mRNA vaccine encoding for a perfusion stabilized form of the spike (S) protein. ${ }^{59}$ It is a vaccine being developed by biotechnology company Moderna in association with national institute of allergy and infectious diseases (NIAID). Interim analysis on Phase I clinical trial of this vaccine is already published on July $14,2020 .{ }^{56}$ Currently the vaccine is in Phase II trials with Phase III trials anticipated to begin in late July with vaccine expected to be out in early 2021.61 Other mRNA vaccines are being developed by bioN tech/fosun pharma/pfizer, curevac and walvax biotech. All are in phase I clinical trials. There are seven vaccines by the different pharmaceuticals industries of China, out of which only one (sinovac) is at the advanced stage of clinical trials (phase III). An illustration of the other coronavirus vaccines under different phases of trials are summed up in (Table 2)..$^{56-61}$

Table 2: Draft of COVID-19 vaccine candidates under human clinical trials.

\begin{tabular}{|c|c|c|c|c|}
\hline S. no. & Vaccine candidate & Platform used & Developer/Company & $\begin{array}{l}\text { Current phase of } \\
\text { human clinical trials }\end{array}$ \\
\hline 1. & INO-4800 & DNA & $\begin{array}{l}\text { Inovio } \\
\text { Pharmaceuticals/San } \\
\text { Diego }\end{array}$ & Phase1/2 \\
\hline 2. & NVX-CoV2373 & $\begin{array}{l}\text { Protein subunit adjuvated } \\
\text { with Matrix-M }\end{array}$ & Novavax & Phase1/2 \\
\hline 3. & BNT162 vaccine & RNA & $\begin{array}{l}\text { Pfizer/BioNtech/Fosun } \\
\text { pharma }\end{array}$ & Phase $1 / 2$ \\
\hline 4. & Covaxin & Inactivated & Bharat Biotech & Phase1/2 \\
\hline 5. & DNA plasmid vaccine & DNA & Cadila Healthcare Ltd & Phase1/2 \\
\hline 6. & Gam-Covid-Vac Lyo & $\begin{array}{l}\text { Non replicating viral } \\
\text { vector vaccine }\end{array}$ & $\begin{array}{l}\text { Gamaleya Research } \\
\text { Institute }\end{array}$ & Phase 1 \\
\hline 7. & $\begin{array}{l}\text { Native like Trimeric } \\
\text { subunit Spike Protein } \\
\text { vaccine }\end{array}$ & Protein subunit & $\begin{array}{l}\text { Clover } \\
\text { Biopharmaceuticals } \\
\text { Inc./GSK/Dynavax }\end{array}$ & Phase 1 \\
\hline 8. & 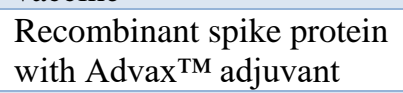 & Protein subunit & Vaxine Pty Ltd/Medytox & Phase 1 \\
\hline 9. & $\begin{array}{l}\text { Molecular clamp stabilized } \\
\text { Spike protein with MF59 } \\
\text { adjuvant }\end{array}$ & Protein subunit & $\begin{array}{l}\text { University of } \\
\text { Queensland/CSL/Seqirus }\end{array}$ & Phase 1 \\
\hline 10. & $\begin{array}{l}\text { Plant derived VLP } \\
\text { adjuvated with GSK or } \\
\text { ynavax adjust. }\end{array}$ & VLP & Medicago Inc. & Phase 1 \\
\hline
\end{tabular}

\section{CONCLUSION}

At present, the control of viral spread is important in order to restrict the transmission of infection. As the incidence is rising rapidly, critical care teams are faced with numerous challenging treatment decisions. The effective communication among the various organizations such as government, industry, national and international bodies is required. Currently, there are no food and drug administration (FDA)-approved agents for the treatment of COVID-19. The medical fraternity is working on a variety of therapies that target different antiviral and immunomodulating mechanisms to combat this virus.
Based on preliminary clinical trial data, the investigational antiviral agent remdesivir is recommended for the treatment of COVID-19 in hospitalized patients with severe disease. The antiCoV potential of these repurposing drugs needs to be validated in clinical trials in order to develop broad-spectrum therapy for Coronavirus infections. In conclusion, all the potential interventions need to be studied and timely implemented to control the emerging COVID-19.

\author{
Funding: No funding sources \\ Conflict of interest: None declared \\ Ethical approval: Not required
}




\section{REFERENCES}

1. Chen N, Zhou M, Dong X, Qu J, Gong F, Han Y et al. Epidemiological and clinical characteristics of 99 cases of 2019 novel coronavirus pneumonia in Wuhan, China: a descriptive study. Lanc. 2020;395(10223):507-13.

2. Adhikari S, Meng S, Wu Y, Mao Y, Ye R, Wang Q et al. Epidemiology, causes, clinical manifestation and diagnosis, prevention and control of coronavirus disease (COVID-19) during the early outbreak period: a scoping review. Infect Disea Pover. 2020;9(1).

3. World Health Organization (2020) Coronavirus disease 2019 (COVID-19) situation report-183. World Health Organization https://www.who.int/docs /default-source/wha-70-and-phe/20200721-covid-19sitrep-183.pdf?sfvrsn=b3869b3_2. Accessed on 22 July 2020.

4. Ashour H, Elkhatib W, Rahman M, Elshabrawy H. Insights into the Recent 2019 Novel Coronavirus (SARS-CoV-2) in Light of Past Human Coronavirus Outbreaks. Pathog. 2020;9(3):186.

5. Chan JF, Yuan S, Kok KH,Wang KK, Chu H, Yang J et al. A familial cluster of pneumonia associated with the 2019 novel coronavirus indicating person-toperson transmission: a study of a family cluster. Lanc. 2020;395(10223):514-23.

6. Ghinai I, McPherson TD, Hunter JC,Kirking HL,Christansen D,Joshi K et al. First known personto-person transmission of severe acute respiratory syndrome coronavirus 2 (SARS-CoV-2) in the USA. Lanc. 2020;395.

7. Chinazzi M, Davis J, Ajelli M, Gioannini C, Litvinova M, Merler S et al. The effect of travel restrictions on the spread of the 2019 novel coronavirus (COVID-19) outbreak. Sci. 2020;9757.

8. Zhang J, Dong X, Cao Y, Yuan Y, Yang Y, Yan Y et al. Clinical characteristics of 140 patients infected with SARS-CoV-2 in Wuhan, China. Allerg. 2020;75(7):1730-41.

9. Xiong Y, Sun D, Liu Y, Fan Y, Zhao L, Li X et al. Clinical and high-resolution CT features of the COVID-19 infection: comparison of the initial and follow-up changes. Investig Radiol. 2020;55(6):3329.

10. Channappanavar R, Perlman S. Pathogenic human coronavirus infections: causes and consequences of cytokine storm and immunopathology. Seminars in Immunopathol. 2017;39(5):529-39.

11. Gordon C, Tchesnokov E, Feng J, Porter D, Götte M. The antiviral compound remdesivir potently inhibits RNA-dependent RNA polymerase from Middle East respiratory syndrome coronavirus. J Biologic Chemis. 2020;295(15):4773-9.

12. Hoenen T, Groseth A, Feldmann H. Therapeutic strategies to target the Ebola virus life cycle. Nat Rev Microbiol. 2019;17(10):593-606.

13. Agostini ML, Andres EL, Sims AC, Graham RL, Sheahan TP, Lu X et al. Coronavirus susceptibility to the antiviral remdesivir (GS-5734) is mediated by the viral polymerase and the proofreading exoribonuclease. MBio. 2018;9(2).

14. Wang M, Cao R, Zhang L, Yang X, Liu J, Xu M et al. Remdesivir and chloroquine effectively inhibit the recently emerged novel coronavirus $(2019-\mathrm{nCoV})$ in vitro. Cell Res. 2020;30:269-71.

15. Pizzorno A, Padey B, Julien T, Trouillet-Assant S, Traversier A, Errazuriz-Cerda E et al. Characterization and Treatment of SARS-CoV-2 in Nasal and Bronchial Human Airway Epithelia. Cell Reports Medicine. 2020;1(4):100059.

16. Sheahan TP, Sims AC, Leist SR, Schafer A, Won J, Brown AJ et al. Comparative therapeutic efficacy of remdesivir and combination lopinavir, ritonavir, and interferon beta against MERS-CoV. Nat Commun 2020;11:222.

17. Barlow A, Landolf K, Barlow B, Yeung S, Heavner $\mathrm{J}$, Claassen $\mathrm{C}$ et al. Review of Emerging Pharmacotherapy for the Treatment of Coronavirus Disease 2019. Pharmacotherapy. J Hum Pharmacol Dr Ther. 2020;40(5):416-37.

18. Grein J, Ohmagari N, Shin D, Diaz G, Asperges E, Castagna A et al. Compassionate Use of Remdesivir for Patients with Severe Covid-19. N Eng J Med. 2020;382(24):2327-36.

19. Williamson B, Feldmann F, Schwarz B, MeadeWhite K, Porter D, Schulz J et al. Clinical benefit of remdesivir in rhesus macaques infected with SARSCoV-2. Natu. 2020;585(7824):273-6.

20. Beigel J, Tomashek K, Dodd L, Mehta A, Zingman B, Kalil A et al. Remdesivir for the Treatment of Covid-19- Preliminary Report. N Eng J Med. 2020;111.

21. Wang Y, Zhang D, Du G, Du R, Zhao J, Jin Y et al. Remdesivir in adults with severe COVID-19: a randomised, double-blind, placebo-controlled, multicentre trial. Lanc. 2020;395(10236):1569-78.

22. Aschenbrenner D. Remdesivir Receives Emergency Use Authorization for Severely Ill Patients with COVID-19. Americ J Nurs. 2020;120(7):26

23. Furuta Y, Gowen BB, Takahashi K, Shiraki K, Smee DF, Brnard DL. Favipiravir (T-705), a novel viral RNA polymerase inhibitor. Antiviral Res. 2013;100(2):446-54.

24. Wang M, Cao R, Zhang L, Yang X, Liu J, Xu M, et al. Remdesivir and chloroquine effectively inhibit the recently emerged novel coronavirus $(2019-\mathrm{nCoV})$ in vitro. Cell research. 2020;30(3):269-71.

25. Kumagai Y, Murakawa Y, Hasunuma T, Aso M, Yuji $\mathrm{W}$, Sakurai $\mathrm{T}$ et al. Lack of effect of favipiravir, a novel antiviral agent, on QT interval in healthy Japanese adults. Int $\mathbf{J}$ Clin Pharmacol Ther. 2015;53(10):866-84.

26. Cai Q, Yang M, Liu D, Chen J, Shu D, Xia J et al. Experimental Treatment with Favipiravir for COVID-19: An Open-Label Control Study. Engineer. 2020

27. Sheahan T, Sims A, Leist S, Schäfer A, Won J, Brown A et al. Comparative therapeutic efficacy of 
remdesivir and combination lopinavir, ritonavir, and interferon beta against MERS-CoV. Natu Communicat. 2020;11(1)

28. Chan JF, Yao Y, Yeung ML, Deng W, Bao L, Jia L, et al. Treatment with lopinavir/ritonavir or interferon$\beta 1 \mathrm{~b}$ improves outcome of MERS-CoV infection in a nonhuman primate model of common marmoset. The J Infect Disea. 2015;212(12):1904-13.

29. Cao B, Wang Y, Wen D, Liu W, Wang J, Fan G et al. A trial of lopinavir-ritonavir in adults hospitalized with severe Covid-19. New Engl J Med. 2020.

30. Knowles SR, Phillips EJ, Dresser L, Matukas L. Common adverse events associated with the use of ribavirin for severe acute respiratory syndrome in Canada. Clinical infectious diseases. 2003;37(8):1139-42.

31. Falzarano D, de Wit E, Rasmussen A, Feldmann F, Okumura A, Scott D et al. Treatment with interferon$\alpha 2 \mathrm{~b}$ and ribavirin improves outcome in MERS-CoVinfected rhesus macaques. Natu Medic. 2013;19(10):1313-17.

32. Elfiky AA. Anti-HCV, nucleotide inhibitors, repurposing against COVID-19. Lif Sci. 2020;248:117477

33. Savarino A, Boelaert JR, Cassone A, Majori G, Cauda R. Effects of chloroquine on viral infections: an old drug against today's diseases? Lanc Infect Dis. 2003;3(11):722-7.

34. Vincent MJ, Bergeron E, Benjannet S, Erickson BR, Rollin PE, Ksiazek TG, et al. Chloroquine is a potent inhibitor of SARS coronavirus infection and spread. Virol J. 2005;2:69.

35. Yao X, Ye F, Zhang M, Cui C, Huang B, Niu P, et al. In vitro antiviral activity and projection of optimized dosing design of hydroxychloroquine for the treatment of severe acute respiratory syndrome coronavirus 2 (SARS-CoV-2). Clinic Infect Diseas. 2020.

36. Gautret P, Lagier J, Parola P, Hoang V, Meddeb L, Mailhe $\mathrm{M}$ et al. Hydroxychloroquine and azithromycin as a treatment of COVID-19: results of an open-label non-randomized clinical trial. Int $\mathbf{J}$ Antimicrob Agen. 2020:105949.

37. Clinicaltrials.gov. Bethesda, MD: National Library of Medicine (US). $2020 \quad$ Feb 19-Identifier NCT04276688, Lopinavir/Ritonavir, Ribavirin and IFN-beta Combination for CoV Treatment; $2020 \mathrm{Feb}$ 28. Available at: https://clinicaltrials.gov/ct2/show /NCT04276688. Accessed on 02 May 2020.

38. Italian ANSA news agency. March 13, 2020. 3 patients get better on arthritis drug. Available at: http://www.ansa.it/english/news/general_news /2020/03/13/3-patients-get-better-on-arthritisdrug_90d4764d-d93f-463e-ab07-168b34b084d0. html. Accessed on 05 May 2020.

39. Xu X, Han M, Li T, Sun W, Wang D, Fu B et al. Effective treatment of severe COVID-19 patients with tocilizumab. Proceed Nation Acad Sci. 2020;117(20):10970-75.
40. Srivastava A. Itolizumab in Psoriasis. Indian J Dermatol. 2017;62(4):418-21.

41. Times of India (internet). Biocon's Itolizumab approved for COVID-19 treatment: All you need to know. Available at: https://timesofindia .indiatimes.com/india/biocons-itolizumab-approvedfor-covid-19-treatment-all-you-need-toknow/articleshow/76957822.cms. Accessed on 18 July 2020.

42. Cao W, Liu X, Bai T, Fan H, Hong K, Song H et al. High-Dose Intravenous Immunoglobulin as a Therapeutic Option for Deteriorating Patients with Coronavirus Disease 2019. Foru Infect Disea. 2020;7(3).

43. Li T, Lu H, Zhang W. Clinical observation and management of COVID-19 patients. Emerg Microbes Infect. 2020;9(1):687-90.

44. Stockman LJ, Bellamy R, Garner P. SARS: Systematic review of treatment effects. PLoS Med 2006;3(9):e343.

45. Russell CD, Millar JE, Baillie JK. Clinical evidence does not support corticosteroid treatment for 2019nCoV lung injury. Lanc. 2020;395(10223):473-5

46. Mahase E. Covid-19: Demand for dexamethasone surges as RECOVERY trial publishes preprint. Brit Med J. 2020;m2512.

47. Tanne JH. Covid-19: FDA approves use of convalescent plasma to treat critically ill patients. Brit Med J. 2020;368

48. Bloch EM, Shoham S, Casadevall A, Sachais BS, Shaz B, Winters JL, et al. Deployment of convalescent plasma for the prevention and treatment of COVID-19. J Clin Invest 2020.

49. Stebbing J, Phelan A, Griffin I, Tucker C, Oechsle O, Smith D et al. COVID-19: combining antiviral and anti-inflammatory treatments. Lanc Infect Disea. 2020;20(4):400-2.

50. ClinicalTrials.gov (2020). Bevacizumab in Severe or Critical Patients With COVID-19 Pneumonia (BESTCP). Available at: https://clinicaltrials.gov/ct2/show/ NCT04275414. Accessed on 20 May 2020.

51. ClinicalTrials.gov (2020). Eculizumab (Soliris) in Covid-19 Infected Patients (SOLID-C19). Available at: https://clinicaltrials.gov/ct2/show/NCT04288713. Accessed on 10 May 2020.

52. Wagstaff KM, Sivakumaran H, Heaton SM, Harrich $\mathrm{D}$, Jans DA. Ivermectin is a specific inhibitor of importin $\alpha / \beta$-mediated nuclear import able to inhibit replication of HIV-1 and dengue virus. Biochem J. 2012;443(3):851-6.

53. Clinicaltrials.gov. 2020. Hydroxychloroquine and Ivermectin for the Treatment of COVID-19 Infection. Available at https://clinicaltrials.gov/ct2/show/ NCT04391127. Accessed on 02 April 2020.

54. Xia J. The Efficacy and Safety of Thalidomide in the Adjuvant Treatment of Moderate New Coronavirus (COVID-19) Pneumonia-Tabular View. Clinic Tria. (2020). Available at: https://clinicaltrials.gov/ ct2/show/NCT04273529. Accessed on 05 May 2020. 
55. Carr A. A new clinical trial to test high-dose vitamin C in patients with COVID-19. Critic Car. 2020;24(1).

56. Draft landscape of COVID-19 candidate vaccines [Internet]. Who.int. 2020. Available at: https://www.who.int/publications /m/item/draftlandscape-of-covid-19-candidate-vaccines. Accessed on 02 April 2020.

57. Folegatti PM, Ewer KJ, Aley PK, Angus B, Becker $\mathrm{S}$, Belij-Rammerstorfer $\mathrm{S}$, et al. Safety and immunogenicity of the ChAdOx1 nCoV-19 vaccine against SARS-CoV-2: a preliminary report of a phase $1 / 2$, single-blind, randomised controlled trial. Lanc. 2020;396(10249):467-78.

58. Smith D. Coronavirus vaccine: Are we close to finding one? Here's what's happening. CNET. 2020 Available at: https://www.cnet.com/howto/coronavirus-vaccine-are-we-close-to-finding-oneheres-whats-happening/. Accessed on 20 July 2020.
59. Belouzard S, Millet JK, Licitra BN, Whittaker GR. Mechanisms of coronavirus cell entry mediated by the viral spike protein. Virus. 2012;4:1011-33.

60. Jackson LA, Anderson EJ, Rouphael NG, Roberts PC, Makhene M, Coler RN, McCullough MP, Chappell JD, Denison MR, Stevens LJ, Pruijssers AJ. An mRNA vaccine against SARS-CoV-2-preliminary report. N Engla J Medic. 2020.

61. Coronavirus Vaccine Tracker. Nytimes.com. 2020. Available at: https://www.nytimes.com/interactive /2020/science/coronavirus-vaccine-tracker.html. Accessed on 20 July 2020.

Cite this article as: Singla S, Kaur A, Kaur M. Insight into ongoing and emerging therapeutic options for COVID-19: a review. Int J Basic Clin Pharmacol 2020;9:1749-56. 